\title{
ANALISA KEJADIAN BANJIR DI KOTA SOLO APRIL 2015
}

\author{
Alfan Muttaqin $^{1}$, Rini Mariana Sibarani ${ }^{2}$
}

\begin{abstract}
Abstrak
Banjir sering dikaitkan dengan fenomena meteorologi yang terjadi dialam. Kota Solo diterjang banjir pada tanggal 22 April 2015. Fenomena meteorologi yang menyebabkan terjadinya banjir tersebut telah dianalisis pada tulisan ini. Analisa meteorologi meliputi Gradien wind, Citra Satelit, Curah hujan dan Peta daerah aliran sungai. Dari segi gradien wind ini terlihat adanya Tropikal Siklon yang berada di Samudra Hindia sebelah selatan Pulau Jawa yang mulai tumbuh pada tanggal 19 April 2015. Tropikal siklon ini sangat mempengaruhi pola angin yang melewati daerah Jawa Tengah dan Yogyakarta, sehingga didaerah itu terbentuk daerah belokkan angin. Hujan yang terjadi sejak tanggal 19 April 2015 menyebabkan material tanah mengalami keadaan jenuh. Tanggal 22 April 2015 awan - awan potensial hujan tebentuk secara merata di daerah Jateng dan Yogyakarta sehingga menyebabkan hujan deras dalam durasi yang cukup lama. Curah hujan yang tinggi didaerah lereng gunung merapi menyebabkan air limpasan masuk kedaerah disekitarnya termasuk Yogyakarta, Boyolali, Sukoharjo dan Solo. Banjir yang terjadi tidak hanya dari hujan lokal namun juga air limpasan dari lereng gunung merapi.
\end{abstract}

Kata kunci : gradien wind, tropical siklon, citra satelit, curah hujan.

\section{PENDAHULUAN}

Indonesia merupakan negara kepulauan sehingga mempunyai sumber air yang melimpah. Air adalah unsur yang sangat penting untuk memenuhi kebutuhan sehari-hari, baik individu ataupun industri. Namun, hampir setiap tahun di Indonesia terjadi banjir. Hal ini dapat disebabkan berbagai macam sebab. Penyebab bencana terbagi dua faktor yaitu faktor external karena adanya perubahan iklim dan faktor internal karena adanya kerusakan lingkungan yang dipicu oleh kegiatan pembangunan yang tidak mengikuti kaidah - kaidah lingkungan.Curah hujan yang tinggi dapat menyebabkan air sungai meluber, terhambatnya saluran-saluran air, media penyerapan air yang sangat sedikit, perusakan lingkungan, dan sebagainya. Banjir akan mengakibatkan berbagai macam kerugian materiil atau mungkin bahkan korban jiwa.

Kota Solo merupakan kota yang lahir dari peradaban sungai Bengawan Solo. Kota Solo sendiri memiliki masalah dengan bahaya bencana banjir dari sungai-sungai yang mengelilinginya. Letak geografis kota Solo yang dikelilingi oleh pegunungan dan perbukitan antara lain bagian selatan ada perbukitan Wonogiri, Gunung Merapi di sebelah barat dan Gunung Lawu di sebelah timur. Letak yang dapat diibaratkan seperti dasar mangkuk ini mengakibatkan wilayah ini sangat rentan terhadap banjir. Air limpasan yang masuk Kota Solo berasal dari tiga arah, yaitu dari lereng Gunung Merapi, lereng Gunung Lawu, dan dataran tinggi Wonogiri.

Banjir besar di kota Solo pernah terjadi pada tahun 1918 dan kemudian pada tahun 1966 kota Solo kembali ditimpa bencana banjir yang lebih besar. Roda pemerintahan dan perekonomian di seluruh kota lumpuh. Bahkan, daerah Sragen, Wonogiri, Sukoharjo, dan Karanganyar turut terkena imbas luapan air sungai Bengawan Solo. Sehingga menimbulkan kerugian berupa korban jiwa, ribuan penduduk yang mengungsi, dan juga kerugian material yang sangat besar. Pada tahun 2007 terjadi lagi banjjir yang menyebabkan lumpuhnya jalan jalan di sekitar kota solo dan kabupaten yang mengelilingi nya antara lain Sukoharjo dan Karanganyar.

Tahun 2015 ini tepatnya di bulan April kota Solo kembali diterjang banjir akibat hujan lebat yang melanda Kota Solo dan sekitarnya dengan intensitas sedang hingga lebat dengan durasi waktu yang cukup lama. Akibat hujan tersebut tidak hanya sungai bengawan solo yang meluap namun juga air limpasan dari lereng gunung merapi yang mengarah ke solo bagian barat menyebabkan waduk Cengklik jebol sehingga sebagian wilayah barat kota solo terendam banjir. Fenomena terjadinya banjir yang menerjang Kota Solo dapat dilihat dari berbagai parameter cuaca. Tulisan ini membatasi kajian terhadap parameter cuaca tersebut antara lain Citra Satelite untuk melihat keberadaan awan pada kejadian banjir, Gradien wind digunakan untuk menganalisis pergerakan massa udara, pola angin dan kejadian ada atau tidaknya pusat tekanan rendah maupun pusaran angin (eddy). Data curah hujan untuk mengatahui banyaknya curah hujan yang turun. Peta daerah aliran sungai digunakan untuk mengetahui aliran air yang akan masuk ke wilayah Kota Solo. Kejadian banjir yang akan dikaji adalah 
banjir di Kota Solo yang terjadi pada tanggal 22 April s/d 24 April 2015 dari parameter cuaca diatas.

\section{DATA DAN METODOLOGI}

Data yang digunakan dalam penulisan paper ini merupakan data sekunder. Definisi Data Sekunder adalah data yang diperoleh melalui pihak lain, tidak langsung diperoleh oleh penulis sendiri.Data Sekunder biasanya berwujud data dokumentasi atau data laporan yang telah tersedia. Data dalam penulisan paper ini diperoleh dari berbagai sumber antara lain :

1. BMKG (Data satelite cuaca di web: Isatelite.bmkg.go.id)

2. Data Curah Hujan (trmm jaxa) yang berasal dari http:Ileorc.jaxa.jp

3. Data Gradien wind berasal dari http:IVbom.gov.au

4. Peta DAS aliran air yang mengalir ke wilayah Solo yang berasal dari bpsdasolo.jatengprov.go.id

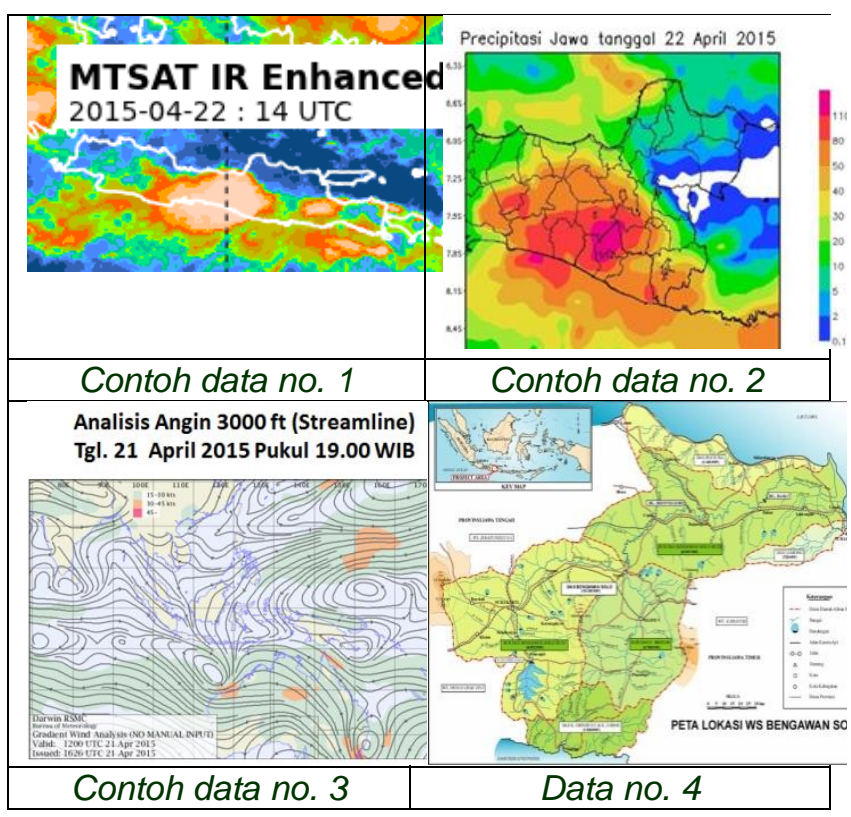

\section{PEMBAHASAN}

Banjir terjadi di Kota Solo pada tanggal 22 April 2015 didaerah Kelurahan Sumber, Kelurahan Banyuanyar, Kelurahan Nusukan, Kelurahan Kadipiro yang dilalui kali Pepe (Solo bagian barat). Selain itu di wilayah Kelurahan Laweyan (Sungai Bengawan Solo) dan yang dilewati Kali Jenes juga terendam (Solo bagian timur).

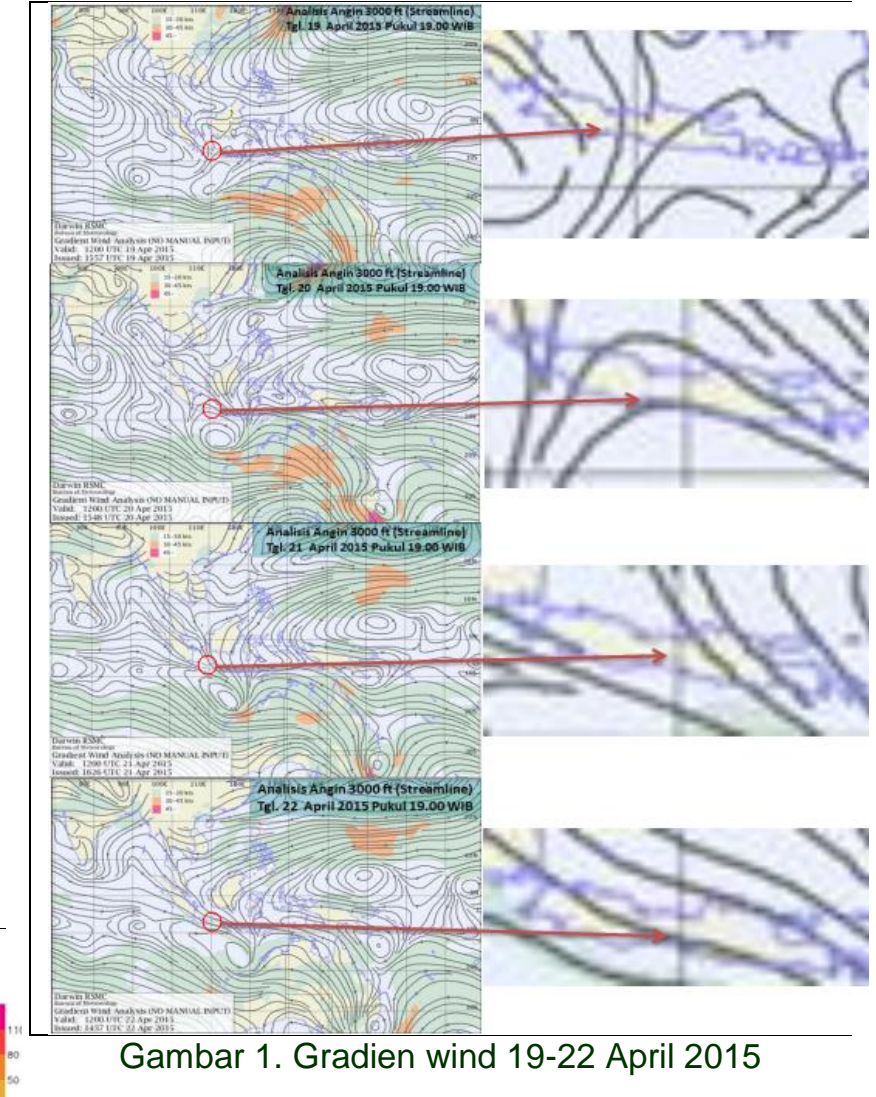

Pola gradien wind yang ditunjukkan pada gambar adalah pola dari tanggal $19-22$ April 2015. Tanggal 19 April 2015 sudah mulai muncul bibit adanya tropikal siklon disebelah selatan pulau jawa. Adanya tropikal siklon ini sangat mempengaruhi pola pergerakan angin di daerah Jawa Tengah dan Yogyakarta. Terlihat dari tanggal 20 - 22 April 2015 dengan adanya tropikall siklon tersebut menyebabkan adanya daerah belokkan angin dan pertemuan angin didaerah sekitar Jawa Tengahdan Yogyakarta sehingga bisa memicu pertumbuhan awan hujan yang potensial. Daerah belokan angin atau pertemuan angin inilah yang mengakibatkan terbentuknya awan-awan konvektif penyebab hujan lebat. Hujan yang terjadi di daerah tersebut bisa terjadi dengan intensitas lebat dan dengan durasi yang ber jam - jam. Kejadian hujan tersebut jika terjadi berhari - hari bisa menyebabkan terjadinya banjir karena luapan sungai yang sudah tidak mampu menampung air hujan ataupun luapan air waduk. Waduk sebagai tempat penampungan air pun bisa jebol jika air yang masuk melebihi jumlah air maksimal yang bisa ditampung oleh waduk. Kejadian jebolnya waduk bisa terjadii tidak hanya karena banyaknya air yang masuk kewaduk namun juga karena tanggul yang tidak dalam keadaan baik.

Terbentuknya awan - awan potensial hujan bisa terlihat dari data citra satelit yang didapatkan dari (satelit.bmkg.go.id). Pengaruh dari tropikal siklon yang berada di selatan pulau jawa sangat berpenagruh terhadap pertumbuhan awan 
- awan potensial seperti yang terlihat pada gambar :

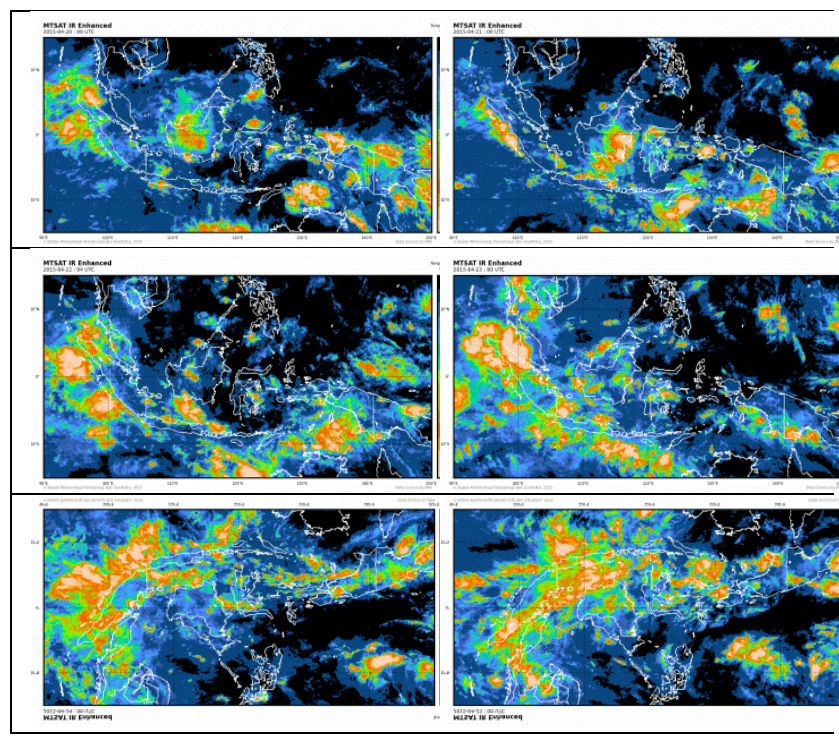

Gambar 2. Animasi citra satelite

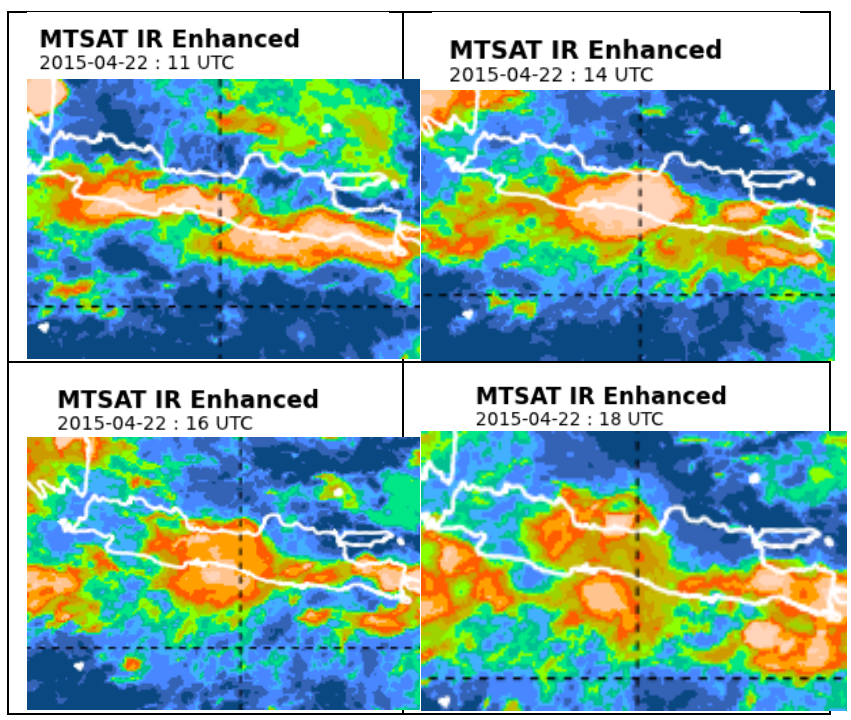

Gambar 3. Citra satelite tanggal 22 April 2015 pukul 11 UTC, 14 UTC, 16 UTC, 18 UTC.

Citra satelit menunjukkan bahwa awan awan potensial hujan memang terbentuk didaerah Jawa tengah dan yogyakarta mulai tanggal 20 April 2015. Sehingga wilayah Jateng dan Yogyakarta mulai diguyur hujan pada tanggal tersebut. Hujan yang mengguyur jika dilihat dari citra satelite mulai intensitas sedang hingga lebat. Pada tanggal 22 April 2015 terlihat kumpulan awan yang terbentuk diatas wilayah Jateng dan Yogyakarta sangat besar dan terjadi dari pukul 11 UTC (18:00 WIB) sampai pukul 18 UTC (01:00 WIB) dini hari tanggal 23 April 2015. Hujan yang terjadi secara merata hampir diseluruh wilayah Jateng dan Yogyakarta dengan intensitas sedang hingga lebat. Hujan tersebut yang menyebabkan wilayah solo bagian barat diterjang banjir dan juga wilayah solo bagian timur yang dilalui sungai bangawan solo juga terendam banjir.
Hujan yang mengguyur wilayah Jawa Tengah dan Yogyakarta pada saat kejadian banjir tersebut bisa dianalisa dengan menggunakan data yang bersumber dari TRMM jaxa (eorc.jaxa.jp). Hasil pengolahan data trrm jaxa menggunakan grads dihasilkan curah hujan hujan seperti yang tertampil pada gambar sebagai berikut :

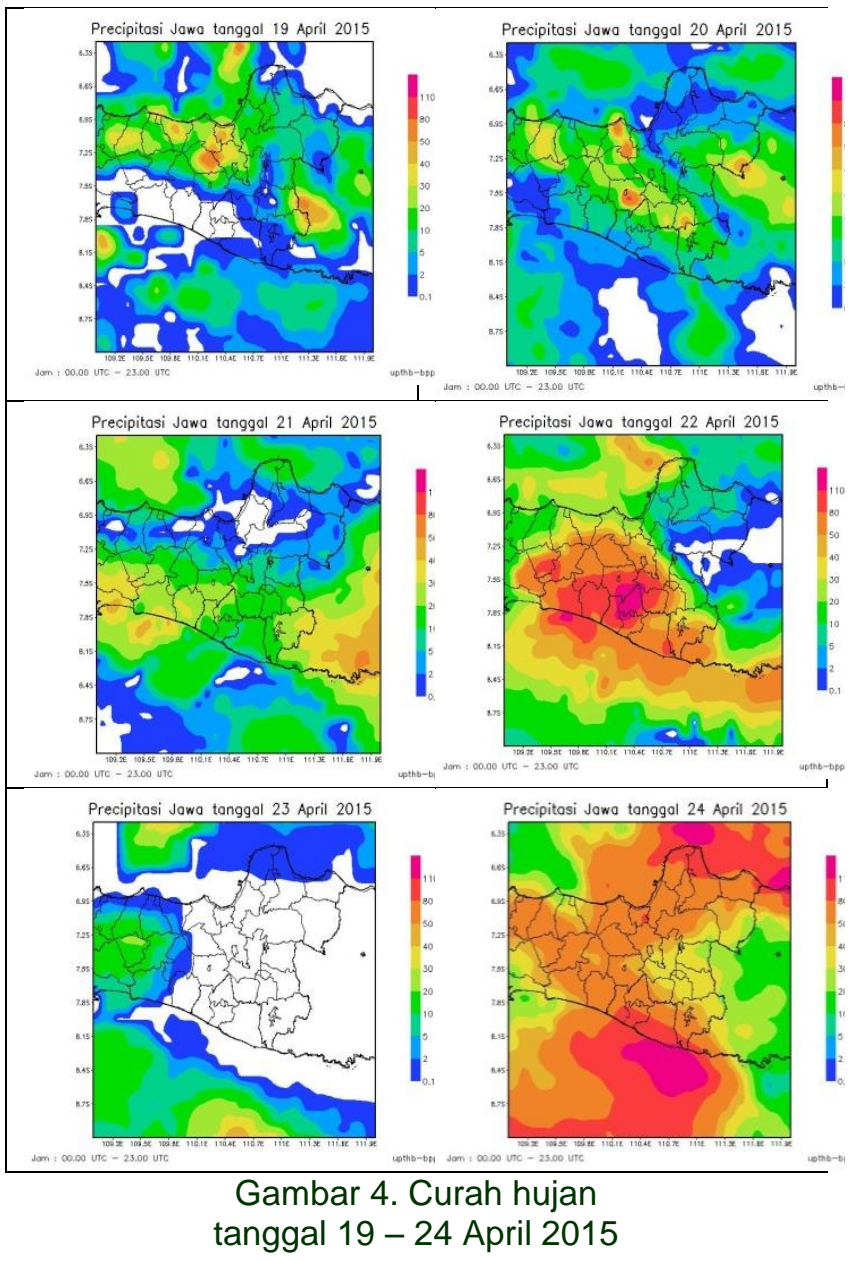

Hujan telah terjadi dari beberapa hari sebelum kajadian banjir. Hujan yang turun tersebut membuat material tanah menjadi jenuh. Sejak tanggal 20 April wilayah Solo dan sebelah barat yaitu daerah lereng gunung merapi terjadi hujan dengan intensitas mencapai $80 \mathrm{~mm}$. Puncaknya pada tanggal 22 April 2015 sebagian besar wilayah Jateng dan Yogyakarta diguyur hujan dengan intensitas mencapai 140mm. Durasi hujan tersebut terjadi dalam waktu yang cukup lama jika dilihat dari citra satelit yaitu selama kurang lebih 7 jam. Hujan yang terjadi dilereng gunung merapi tersebut membuat sub das merapi meluap yang menyebabkan air limpasan masuk ke wilayah selatan ke daerah Yogyakarta dan sebelah timur ke daerah Boyolali, Sukoharjo dan juga daerah Solo bagian barat.Air limpasan dari lereng gunung merapi masuk ke kota solo melalui kali Pepe yang melintasi tengah kota solo sehingga kali Pepe meluap dan menyebabkan banjir diwilayah kota Solo. Hujan yang terjadi diwilayah hulu waduk 
wonogiri juga menyumban air limpasan yang masuk ke das bengawan solo yang menyababkan wilayah solo bagian timur terendam banjir akibat luapan sungai bengawan solo.

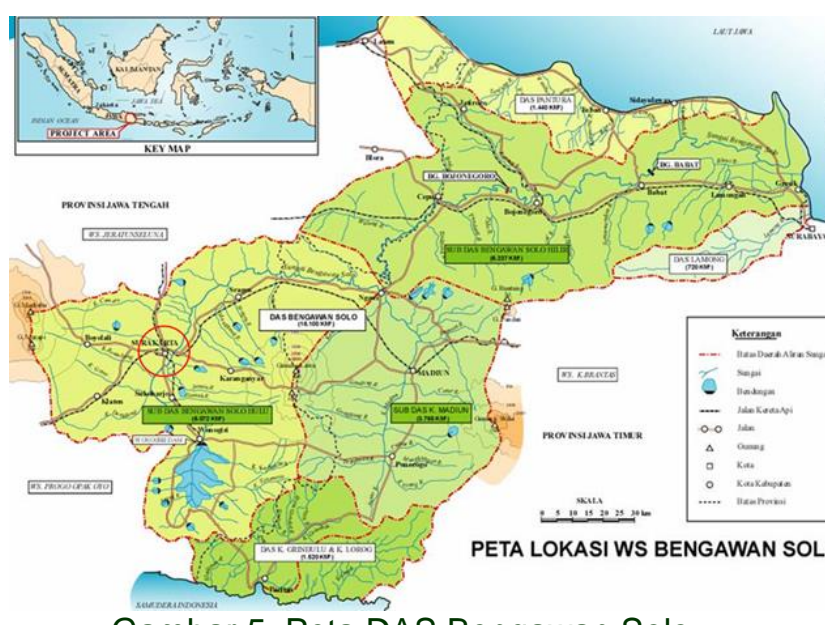

Gambar 5. Peta DAS Bengawan Solo

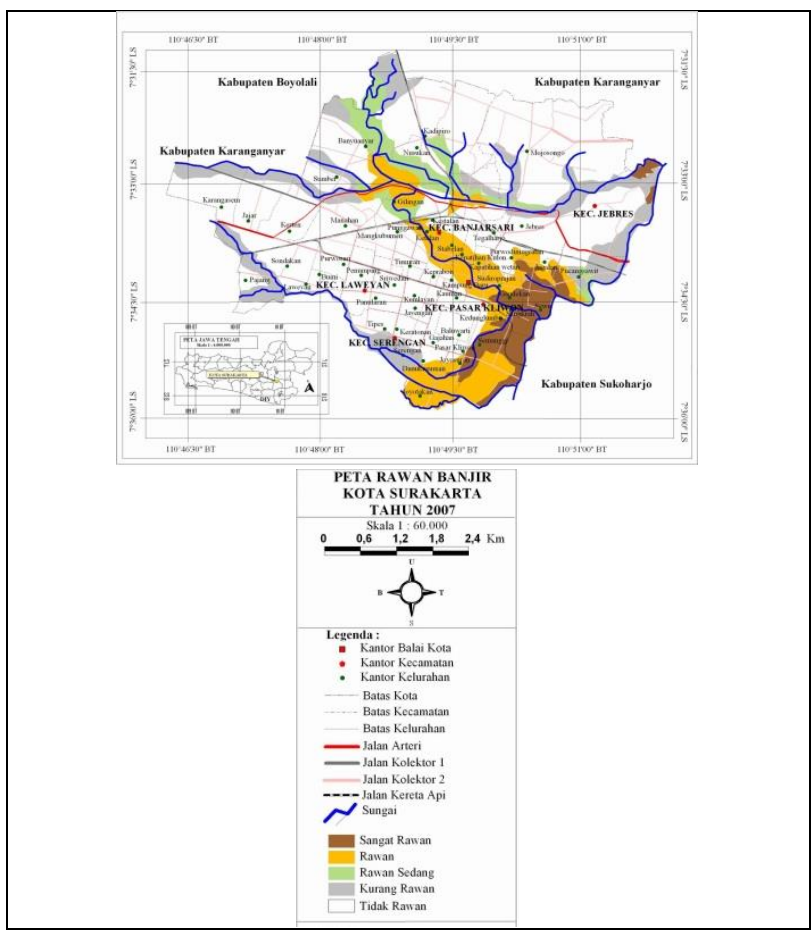

Gambar 6. Peta daerah rawan banjir kota Solo

Dilihat dari gambar peta DAS bengawan solo menunjukkan bahwa adanya aliran air dari lereng gunung merapi. Sehingga banjir yang menggenang daerah Sukoharjo, Boyolali dan Solo bagian barat tidak hanya disebabkan tingginya intensitas curah hujan pada daerah tersebut namun juga pengaruh air kiriman dari hujan yang terjadi didaerah lereng gunung merapi. Dari gambar peta wilayah rawan banjir di Solo memang Solo bagian barat daerah Banyuanyar termasuk Rawan dengan kategori sedang hingga rawan. Solo bagian timur daerah Kampung Sewu merupakan daerah rawan dengan kategori sangat rawan.

\section{KESIMPULAN DAN SARAN}

\subsection{Kesimpulan}

1) Adanya tropikal siklon di selatan pulau jawa (samudra hindia) sangat mempengaruhi curah hujan didaerah Jateng dan Yogyakarta.

2) Banjir yang terjadi didaerah Jateng dan Yogyakarta disebabkan intensitas hujan yang cukup tinggi dan air limpasan dari lereng Gunung Merapi.

\subsection{Saran}

1) Sebaiknya dibuat resapan dimasing masing kabupaten/kota dan juga pengerukan sungai agar tidak dangkal sehingga aliran air tidak meluber dan menyebabkan terjadinya banjir.

\section{DAFTAR PUSTAKA}

Asdak, Chay. 2004. Hidrologi dan Pengelolaan Daerah Aliran Sungai. Yogyakarta: Gadjah Mada University Press.

Handoko,Ir.1986. Klimatologi Dasar. Bogor: Jurusan geofisika dan Meteorogi,FMIPAIPB.

Kuntowijoyo, 2000. The Making of a Modern Urban Ecology: Social and Economic History of Solo, 1900-1915, (Yogyakarta: Jurusan Sejarah Fak. Sastra UGM)

Sanusi, Muhammad Nunu. 2009. Prediksi Penyebaran Banjir Disitus Bengawan Solo Berdasarkan Curah Hujan Dan Elevasi Permukaan Tanah. ITS Surabaya

http://satelite.bmkg.go.id

http://eorc.jaxa.jp

http://bom.gov.au

http://bpsda-solo.jatengprov.go.id

\section{Berita}

http://sp.beritasatu.com/home/ini-adalah-banjirterbesar-di-solo/84960

http://www.solopos.com/2015/04/23/banjir-solobegini-penampakan-banjir-di-soloraya597517

http://nasional.tempo.co/read/news/2015/04/23/05 8660175/bnpb-banjir-masih-menggenangiyogyakarta-dan-solo

http://www.solopos.com/2015/04/24/banjir-solobanjir-rabu-2242015-malam-lebih-parahdari-2008-597856 
